\title{
Staplercide!
}

\section{The lives and deaths of academic library staplers}

W

e have experienced 15 deaths in my library this semester. Three victims were decapitated. The bodies of two other victims were never found. Others were abused and left for dead. My library is facing a crisis. Staplercide - the murder of library staplers-is at an all-time high.

The average life span for a stapler at my library's reference desk this past semester was 15.3 days. The most common cause of stapler death was exhaustion. An exhausted stapler would staple once, and then jam, entering a state of nonresponsive "stapler shock." After a librarian

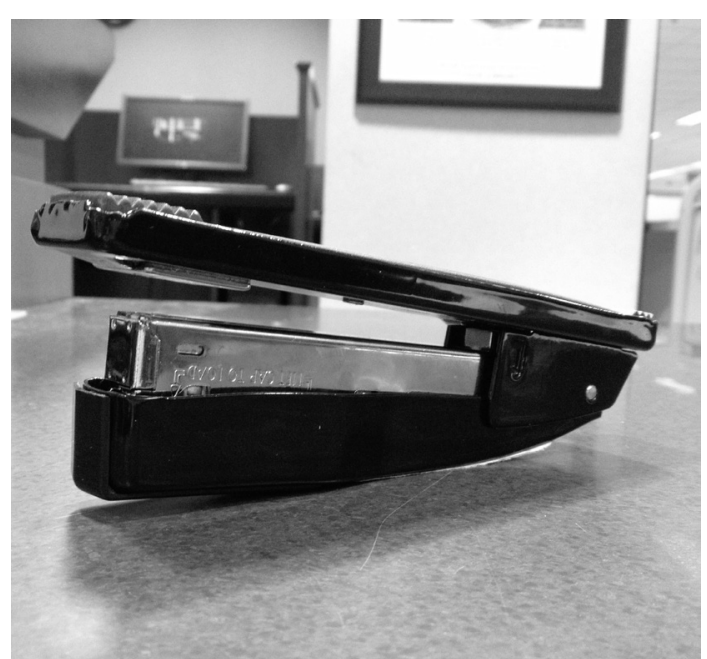

Stapler 9 is dead at the age of 36 days. librarians around the world tend to injured and abused staplers and bring them back from near-death experiences. This semester, however, as the carnage raged at my library, I felt more like a coroner than a nurse.

In January 2013, curiosity and concern drove me to begin documenting the rampant destruction of staplers at my library's reference desk.

With help from my colleagues, I discreetly numbered each stapler and noted the date as we put it out for public use. I photographed each stapler and documented it on a Tumblr page I created for this project. $^{2}$ When valiantly unjammed it, the stapler would muster one more staple before collapsing again. Often we were not able to intervene before a frustrated student began assaulting the jammed stapler. One should not beat a dead stapler. ${ }^{1}$

Like many seasoned reference librarians, experience at the reference desk has turned me into a self-taught stapler triage nurse. Armed with the tools of our trade-screwdrivers, tweezers, and pliers-reference each stapler died, I recorded the date and calculated its age in a spreadsheet. Later I added the results of my stapler autopsy and indicated the cause of death.

Some staplers lasted no more than one day. The longest living stapler succumbed

Jason Vance is information literacy librarian at Middle Tennessee State University's James E. Walker Library, e-mail: jason.vance@mtsu.edu

(c) 2013 Jason Vance 
at the age of 45 days. May they all rest in peace.

We have tried buying different staplers. The staplers we now purchase are Swingline's Commercial Desk Staplers (Model No. S7044401). The list cost is $\$ 25.77$. These are nice, high-quality staplers. We buy this model because they last longer than the others we have tried in the past. Plus, Swingline offers a "limited lifetime warranty" on its products. If a customer returns a dead stapler that died with no signs of foul play (my words, not theirs) accompanied by a receipt or proof of purchase, Swingline will send the customer a replacement stapler. To save on shipping costs, I began collecting dead staplers on my desk. My office quickly became a cemetery.

We also tried offering our students an electric stapler. Shortly after it was put

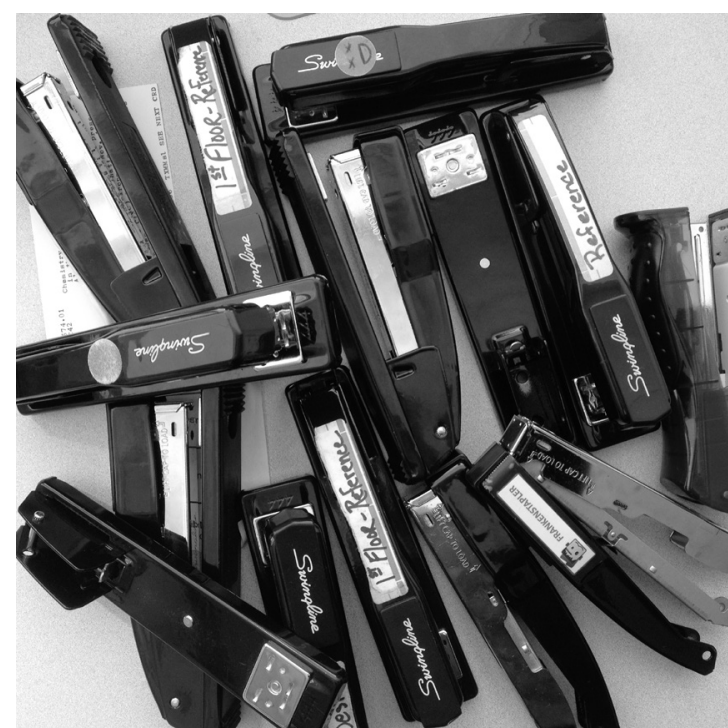

A dead stapler funeral pyre.

\section{Staplercide - the murder of library staplers-is at an all-time high.}

are savages. Perhaps they are. But evidence suggests that we are not alone. As word of my morbid investigations began to spread via social media, letters of support and sympathy poured in from other libraries.

Further evidence of this pandemic can be found in the October 2000 issue of Indiana University's law library newsletter, "Res Ipsa Loquitur." The library's associate director described scenes where law students were observed placing staplers on the floor and "using their feet to push the levers." She added, "We cannot continue to use Library resources to purchase staplers that are going to be abused. The solution is in your hands-take care out for public use,

one of our librarians found it with its electrical cord severed. She described a grisly scene. The stapler lay lifeless on the counter, while its ripped power cord was still plugged into the wall. Its naked wires were left exposed as it lay abandoned by the perpetrator. No one knows what happened. Perhaps it was an errant swipe of the neighboring paper cutter blade? Or maybe some anti-technology campus radicals were using violence to make a political statement? Either way, it was an expensive piece of machinery and was not replaced. The suspected foul play voided the terms of the manufacturer's warranty.

At this point, you must think our students of the staplers, use them properly, and we will continue to provide them." ${ }^{3}$ Res ipsa loquitur, indeed.

Sometimes frustration can spark creativity. Working in an office filled with dead staplers, I had a flash of inspiration midway through my study. I asked myself, "Why not build a new working stapler using spare parts from dead staplers?" Like a mad scientist in a tower laboratory, I used a quiet spring break week at my university to work on my new top-secret project. The sounds of clanging metal, unbound springs, and incessant hammering emanated from my closed office door. All that was missing was a thunderstorm and a bolt of lightning. 
Finally, when my project was complete, my maniacal laughter was followed by my cry, "It's alive! It's alive!" I dubbed my creation, "Frankenstapler," and released it at the reference desk.

To quote Robert Walton from Mary Shelley's Frankenstein, "What can stop the determined heart and resolved will of man?" As if in answer to this question, our library patrons destroyed my Frankenstapler after only 27 days.

Another creative venture borne of this staplercide

crisis came

from Wil-

liam Den-

ton, Web

librarian at

York University and

a fellow

library sta-

pler activist.

We can

replace the

word $l i$ -

brary with

Tweet from a library stapler activist.
With no actual American Library Stapler Association and only the dream of a smart LibStapler, what are reference librarians to do?

Librarians must celebrate the lives of library staplers, however short, and mourn their deaths when they pass. Staplers are destroyed primarily because they are used. Despite the New York Times' assertion that staplers are dusty and unused in this digital age of PDFs, ${ }^{5}$ reference librarians know that each of our dead academic library staplers is going down in a blaze of glory. And when a student kills one of our staplers, another one will rise up to meet the fastening challenges of the day.

However much we want to protect our staplers from our patrons, we must remember the first of Ranganathan's pler in our professional conversations and joke about the American Library Stapler Association. Or we imagine ourselves reading the latest issue of College \& Research Library Staplers News. Or how about studying Ranganathan's Five Laws of Library Stapler Science? The possibilities are endless.

Springshare, purveyors of the popular LibGuides product, also got in on the stapler humor action. They announced a fake product, the LibStapler, as an insensitive April Fools' joke. Billed as the "Smart Stapler for Libraries," the LibStapler purported to offer stapler usage statistics, SMS text alerts when staples were running low, diagnostic alerts, and a built in security camera to "catch that person trying to staple more than 20 pages at a time. ${ }^{\prime 4}$ If this product were real, libraries would pay top dollar for it. But libraries can't buy a nonexistent product, so the joke is on you, Springshare.
Five Laws of Library Stapler Science: "Staplers are for use."

\section{Notes}

1. See the February 2012 parody article, "Evolutionary Basis of Stapler-Induced Human Aggression and Psychopathology," in the nonexistent Apocryphal Evolution and Human Behaviour, http://libraryshenanigans.files. wordpress.com/2012/07/paper.pdf, accessed April 11, 2013.

2. Jason M. Vance, "The Lives and Deaths of Academic Library Staplers," http:// deadstaplers.tumblr.com, accessed April 11, 2013.

3. "Suggestion Box," "Res Ipsa Loquitur," 11, no. 2 (October 2000): 3.

4. Springshare, "LibStapler," http:// springshare.com/libstapler, accessed April 1, 2013.

5. Phyllis Korkki, "The Attachment that Still Makes Noise," New York Times, March 24, 2013: BU1. 